\title{
The Effect of Callyspongia biru Antibacterial Extract Concentration towards the Growth of Bacterial Isolates of Kappaphycus Alvarezii Seaweed with Ice-ice Disease
}

\author{
${ }^{1}$ Feliksitas Angel Masing, ${ }^{2}$ Moses Kopong Tokan \\ ${ }^{1}$ Universitas Timor, Kefamenanu \\ ${ }^{2}$ Universitas Nusa Cendana, Kupang \\ Email Correspondence:feliksitasm@gmail.com
}

\author{
Article Info \\ Article History \\ Received:28 August 2021 \\ Revised:18 September \\ 2021 \\ Published: 25 August 2021 \\ Keywords \\ Callyspongia biru, \\ antibacterial, \\ Kappaphycus alvarezii, \\ ice-ice disease.
}

\begin{abstract}
This research was conducted at the Biology Education Laboratory, Faculty of Teacher Training and Educational Sciences, Nusa Cendana University, with the aim of knowing the effect of the concentration of the antibacterial extract of Callyspongia biru on the growth of bacteria that caused Ice-ice disease. The method used in this study was an experimental method, with a Completely Randomized Design (CRD) consisting of 4 treatments (concentration of Callyspongia biru extract of 10\%, 20\%, 30\% and 40\%) with 3 times repetition. Therefore, the total treatment units were 12 units. The parameter that has been measured in this study was the diameter of the inhibition zone. The inhibition zone diameter data was then analyzed by using one-way ANOVA with the Tukay method.If Fcount is greater than Ftable then it would be tested further using Honest Reality Difference test at 5\% significant level. The result showed that the different concentrations of Callyspongia biru extract gave significantly different effects on the growth of bacterial isolates from seaweed Kappaphycus alvarezii with Ice-ice disease. At a concentration of 40\%, Callyspongia biru extract showed the strongest average inhibition of $27.67 \mathrm{~mm}$.
\end{abstract}

C) 2021 Science Education Study Program FKIP Unisla Lamongan.

Citations: Masing, F. A. \& Tokan, M. K. (2021). The Effect of Callyspongia biru Antibacterial Extract Concentration towards the Growth of Bacterial Isolates of Kappaphycus Alvarezii Seaweed with Ice-ice Disease. Science Education and Application Journal, 3 (2), 102-112.

\section{INTRODUCTION}

The abundance of marine life in our country makes it rich in marine products and certainly become one of the exporting countries of marine products in the world. East Nusa Tenggara province stores regional income assets from marine products such as seaweed. Kupang Regency is one of the seaweed cultivation areas in East Nusa Tenggara Province (National Water Conservation Area Agency, NTT province, 2020).

The coastal and marine areas of Kupang Regency have rich natural resource potential such as mangrove forests, sea grass beds, seaweed, various types of coral reefs, fisheries and other marine biota (Temu et al, 1999 in Kamlasi, 2011). The coastal area of the West Kupang District, one of the sub-districts in Kupang Regency, has the potential of water resources for business development in the field of fisheries (cultivating and catching). Seaweed cultivation is one of the potential being developed currently. Seaweed is one of the marine resources that has benefits for the food, pharmaceutical, and other industries because it produces agar, carrageenan and alginate. Seaweed also contains carbohydrates, protein and a little fat as well as sodium and potassium salt compounds. Utilization of coastal and marine biological resources such as seaweed and others has long been carried out by seaweed farming communities in West Kupang District. So far, people have been using seaweed to be limited to nature and few are cultivating it. The type of seaweed that is cultivated and utilized in this 
area is the Eucheuma seaweed (Kamlasi, 2011). Eucheuma seaweed dominates Indonesia's production and exports. Indonesia is even the number two the supplier of Kappaphycus alvarezii seaweed in the world after the Philippines (Kordi, 2011).

The main obstacle of seaweed cultivation is the presence of ice-ice disease that attacks seaweed before the change of seasons. The disease impacts the decline in seaweed production resulted in a decrease of farmers' income. This ice-ice disease is the cause of failure of seaweed cultivation (Tokan, et al. 2012). The development of pathogenic bacteria activity in the seaweed thallus resulted in the appearance of white spots on the thallus and gradually became porous and finally the thallus was broken. Symptoms of ice-ice disease are generally characterized by bleaching at the base of the thallus, middle and tip of the young thallus, which begins with a change in color of the thallus to clear white or transparent. In general, the spread of ice-ice disease occurs vertically by thallus seeds and horizontally through the mediation of water (DKP, 2004 in Aris, 2011). Until now, this disease has not been overcome. The main difficulty in controlling this disease is the existence of a marine environment as a place for seaweed growth. Controlling this disease becomes too difficult because of the water environment. There is no barrier between one cultivation location and another, as well as there is no barrier between one rope and another. Thus, when an ice-ice disease invades, other cultivation locations or ropes will be susceptible to attacked. This is because water is a medium for the spread of disease (Tokan et al, 2012). Another alternative that can be applied is biological control by using Callyspongia sponges. Callyspongia is an animal, so if it is used as a companion organism in seaweed cultivation, it will be more profitable. This is because the competition for nutrients will not occur. Moreover, there will be mutual fulfillment of each other's needs. Callyspongia provides CO2 to meet the photosynthetic needs of seaweed, and on the other hand seaweed provides $\mathrm{O} 2$ for Callyspongia's respiration needs. The fact shows that some types of Callyspongia produce secondary metabolites with biological activity (Tokan et al, 2012).

Secondary metabolites of this sponge have been reported to have anticancer, antimicrobial and anti parasitic activity (Amir and Budiyanto, 1996). Immaculata (2007) in Tokan et al (2012) suggested that in the waters of Kupang Bay there were a number of Callyspongia species showing antimicrobial potential against test bacteria and Callyspongia biru showed the strongest inhibition compared to others. Voogd et al. (2006) in Fariska (2010) stated that Callyspongia biru has a higher bio activity than the sponges Amphimedon paraviridis, Niphates olemda, and Aaptos suberi-toides. Because of its ability to produce bio actives including antibacterial, research on controlling ice-ice disease in seaweed has also used Callyspongia as a companion and the results are quite encouraging because it can reduce the attack of ice-ice disease (Tokan and Oheli, 2010 in Tokan, 2011). The purpose of this research was to determine the effect of the concentration of Callyspongia biru extract on the growth of bacterial isolates from seaweed Kappaphycus alvarezii with ice-ice disease and to determine the concentration that produced the strongest inhibition on the growth of bacterial isolates from seaweed Kappaphycus alvarezii with ice-ice disease. This research is useful as information material for agencies engaged in marine and fisheries as well as seaweed farming communities so that they can use Callyspongia biru as a bioprotector for seaweed, as well as for researchers who are interested in conducting further research.

\section{METHODS}

The Callyspongia biru was taken from Timor Beach and seaweed samples were gotten from Tablolong Beach, Kupang, East Nusa Tenggara.

\section{Tools and Materials}

a. Tools. The tools used in this research are incubator, Laminar Air Flow, micropipette (1000 $\mu \mathrm{l}$ and $200 \mu \mathrm{l})$, measuring pipette, autoclave, hot plate, petri dish, inoculation loop, analytical balance, test tube, erlenmeyer $1000 \mathrm{ml}$, measuring cup (200 ml), 
Sensidisc dispenser, funnel, mortar, maceration container, vacuum evaporator, spirit lamp and water bath.

b. Material. The materials used in this study were dry explants of Callyspongia biru, bacterial isolates from seaweed Kappaphycus alvarezii with ice-ice disease, modified NA medium, MHA medium, aquades, $30 \mathrm{~g}$ tetracycline and gasoline petrol.

2. Research Design

This study is an experimental study, using a Completely Randomized Design (CRD) consisting of 4 treatments (concentration) with 3 replications. There are 12 experimental units total.

3. Work Procedure

a. Room preparation. The room of inoculation was cleaned and sprayed with alcohol to sterilize other microorganisms.

b. Preparation of tools and materials. The tools and materials used in this research were prepared in the laboratory. Pure cultures of isolated bacterial from seaweed with iceice disease were obtained from the rejuvenation results in the P. Biology laboratory.

c. Manufacture of modified NA medium (Seawater NA). Seawater NA medium is a growth medium for bacterial isolates from seaweed with ice-ice disease. This medium is made by adding $150 \mathrm{~mL}$ of meat extract then adding $300 \mathrm{~mL}$ of sea water and then heating it on a hotplate. Then dissolve the agar and add seawater until the volume reaches $500 \mathrm{ml}$. Then it was removed and poured into $10 \mathrm{~mL}$ petri dishes each and allowed to cool.

d. Isolation of bacteria from seaweed Kappaphycus alvarezii with ice-ice desease. Bacterial isolates from seaweed with ice-ice disease are readily available at the Biology Laboratory of FKIP UNDANA, from student research. This bacterial isolate consisted of Vibrio sp and Pseudomonas sp.

e. Preparation of Callyspongia biru extract. The extracts of the Callyspongia biru were made by using the maceration method while the solvent used was petroleum gasoline. The dried extract of the Callyspongia biru type was cut into small pieces/mashed and weighed as much as 300 grams, then were put in a maceration container and added $750 \mathrm{ml}$ of gasoline gasoline solvent, let stand for 5 days while stirring occasionally. Furthermore, it is filtered and the extract obtained is accommodated and concentrated until it became thick with a vacuum evaporator at a temperature of $80.1^{\circ} \mathrm{C}$ according to the boiling point of gasoline gasoline. Petrol gasoline is a non-polar solvent (Tokan, 2012). Harbone (1983) in Tokan (2012) explains that the principle of solubility is that polar solvents will dissolve polar compounds, semi-polar solvents will dissolve semi-polar compounds and non-polar solvents will dissolve non-polar compounds. So the extract obtained is an extract containing non-polar compounds.

f. Rejuvenation of test bacteria Staphylococus aureus and Escherichia coli were used as a comparison of resistance with isolates obtained from ice-ice diseased seaweed. These test bacteria were inoculated in inclined NA medium and incubated at $37^{\circ} \mathrm{C}$ (optimum temperature for growth of both types of test bacteria) for 24 hours.

g. Preparation of MHA medium $500 \mathrm{ml}$ of aquadest was heated on a hot plate. Then 20 grams of MHA powder was added. After that stirred and heated until thick. The finished MHA medium is removed and ready to be used. This MHA medium need to be sterilized before being used. The MHA medium was put in an Erlenmeyer flask, covered with aluminum foil, then sterilized using an autoclave with a pressure of \pm 1.5-2 atm and at a temperature of $121^{\circ} \mathrm{C}$ for 35 minutes.

h. Preparation of extract concentration Callyspongia biru. Based on the results of research by Suryati and Mulyani (2002) regarding the effectiveness of the use of bio active sponges for bacterial control, it is known that the sponge extract of the 
Callyspongia sp species is able to kill bacteria maximally at a concentration of $20 \%$. Therefore, in this study the concentration of $20 \%$ will be determined as the middle concentration which will be increased twice up and twice down, calculated by multiples of 10 . So that the concentration is $40 \%, 30 \%, 20 \%$ and $10 \%$ while $0 \%$ was used as a negative control. How to make Callyspongia biru extract, namely: a) $40 \%=$ $4.0 \mathrm{ml}$ of extract diluted with sterile distilled water until the volume reaches $10 \mathrm{ml} \mathrm{b}$ ) $30 \%=3.0 \mathrm{ml}$ of extract diluted with sterile distilled water until the volume reaches $10 \mathrm{ml}$. c) $20 \%=2.0 \mathrm{ml}$ of extract diluted with sterile distilled water until the volume reaches $10 \mathrm{ml}$. d) $10 \%=1.0 \mathrm{ml}$ of extract diluted with sterile distilled water until the volume reaches $10 \mathrm{ml}$. e) $0 \%=0 \mathrm{ml}$ of extract diluted with sterile distilled water until the volume reaches $10 \mathrm{ml}$. This concentration is also negative.

i. Preparation of Comparison Solution Tetracycline was weighed as much as 0.00030 grams and dissolved in sterile distilled water until the volume reached $10 \mathrm{ml}$, so that a concentration of $30 \mathrm{~g} / \mathrm{ml}$ was obtained.

j. Testing the antibacterial inhibition of Callyspongia biru extract against bacterial isolates from seaweed and test bacteria. $10 \mathrm{ml}$ of MHA medium was poured aseptically into a petri dish and allowed to freeze as a base layer. A total of $5 \mathrm{ml}$ of MHA medium which was slightly cooled at 45 - $48 \mathrm{C}$, after being thoroughly mixed with the test bacteria, was poured over the bottom layer of the medium and spread evenly using a sterile speeder. Furthermore, the sensidisk or cover is placed on the surface of the medium and filled with $0.2 \mathrm{ml}$ of the comparison solution and the test solution. For 1 medium consisted of 6 pens which were divided into 1 positive control containing tertracycline, 1 negative control ( $0 \%$ extract concentration) and 3 pens with different concentrations of the extract of the bioactive compound Callyspongia biru then incubated at $37 \mathrm{C}$. for 24 hours. Furthermore, the diameter of the inhibition zone or the distance that is not overgrown with bacteria is measured with a caliper. Determination of the inhibition of bacterial isolates based on Cappuccino and Sherman (1983) and Prescott et al. (1990) and according to Davis and Stout (1997).

\section{Data Collection}

The data needed in this study is the diameter of the inhibitory zone of the antibacterial compound of Callyspongia biru from each treatment concentration.

\section{Data Analysis and Interpretation}

Data on the zone of inhibition of antibacterial were analyzed by one-way ANOVA at a significance level of 5\% with the SPSS for Windows version 14 program. To see the differences between treatments, further analysis was carried out with $5 \%$ BNJ. If the calculated $\mathrm{F}$ value (treatment with different concentrations) is greater than $\mathrm{F}$ table, it can be concluded that the difference in concentration has a significantly different effect on the inhibition of bacterial isolates from seaweed Kappaphycus alvarezii with ice-ice disease.

\section{RESULTS AND DISCUSSION}

\section{Callyspongia biru Antibacterial Extract}

In this study, 300 grams of Callyspongia birupowder was weighed and macerated with $750 \mathrm{ml}$ of gasoline as solvent. This maceration process occurred for 5 days while stirring occasionally, then evaporated and obtained $21 \mathrm{ml}$ of black filtrate. Then $10 \mathrm{ml}$ of the filtrate was taken to make concentrations of $10 \%, 20 \%, 30 \%$ and $40 \%$ by dilution.

\section{2. $\quad$ Tested Bacteria}

The tested bacteria were taken from the seaweed Kappaphycus alvarezii suffered ice-ice, which consisted of Vibrio sp and Pseudomonas sp.. The bacteria were taken at a dilution rate of 10-4. Prior to the research, these bacteria were rejuvenated for 24 hours 
in an incubator at $30^{\circ} \mathrm{C}$. There are also other bacteria used as comparisons in this study, namely S. aureus as a representative of gram-positive bacteria and E.coli as a representative of gram-negative bacteria. These two bacteria were also rejuvenated for 24 hours in an incubator. As a negative control, sterile distilled water was used.

3. Inhibition Zone Diameter Data

Callyspongia biru extract can inhibit the growth of bacteria that cause ice-ice disease as well as comparison bacteria, namely S. aureus and E. coli as seen from the clear zone that appears after incubation for 24 hours. The following table shows the result of laboratory test on the effect of the concentration of Callyspongia biru extract towards the bacteria that cause ice-ice disease in Kappaphycus alvarezii seaweed.

Table 1. Inhibitory Zone Diameter of Callyspongia biru extract towards bacteria causing ice-ice disease in seaweed Kappaphycus alvarezii E.cottonii

\begin{tabular}{|c|c|c|c|c|c|c|}
\hline \multirow{2}{*}{ Treatment (\%) } & \multicolumn{4}{|c|}{ Inhibition Zone Diameter (mm) } & \multirow{2}{*}{ Amount } & \multirow{2}{*}{ Average } \\
\hline & 1 & 2 & & 3 & & \\
\hline $\mathrm{K}_{1}$ & 17 & 19 & 18 & & 18 & 18 \\
\hline $\mathrm{K}_{2}$ & 20 & 21 & 20 & & 20 & 20,33 \\
\hline $\mathrm{K}_{3}$ & 23 & 25 & 22 & & 22 & 23,33 \\
\hline $\mathrm{K}_{4}$ & 27 & 30 & 26 & & 26 & 27,67 \\
\hline $\mathrm{K}^{+}$ & 18 & 20 & 22 & & 22 & 20 \\
\hline $\mathrm{K}^{-}$ & - & - & - & & - & - \\
\hline
\end{tabular}

Note table 1:

$\mathrm{K} 1=10 \%$ concentration

$\mathrm{K} 2=20 \%$ concentration

$\mathrm{K} 3=30 \%$ concentration

$\mathrm{K} 4=40 \%$ concentration $\mathrm{K}+$ (positive control): Tetracycline $\mathrm{K}$ - (negative control): sterile Aquades

Table 1 above shows the average value of the diameter of the different inhibition zones at each treatment concentration. The average value of the smallest inhibition zone diameter was at a concentration of $10 \%$, i.e 18 , while the largest was at a concentration of $40 \%$, i.e 27.67. The difference in the effect of the concentration of Callyspongia biru extract on the growth of ice-ice bacteria isolates can also be seen more clearly in Figure 1 below.

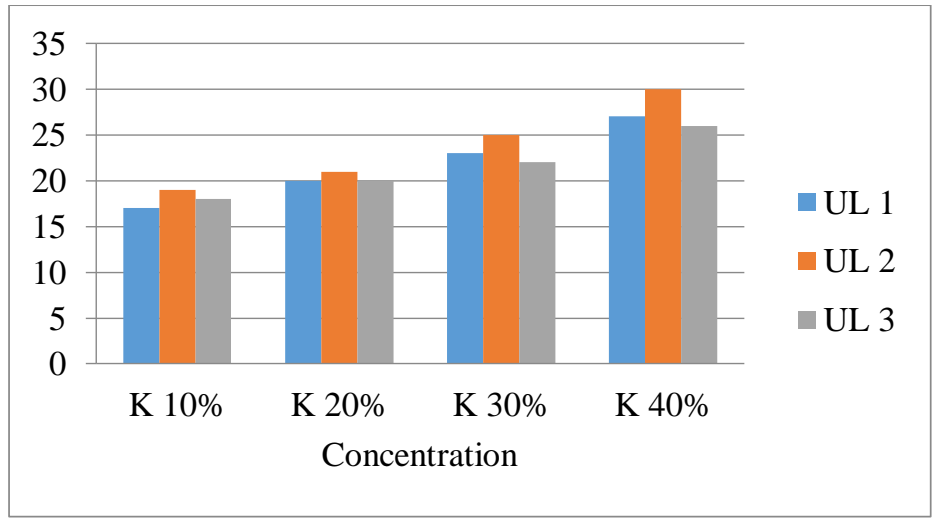

Figure 1. Graph of the average difference on the effect of the concentration of Callyspongia biru extract towards the growth of ice- ice bacteria.

From Figure 1 above, it is clear that the average diameter of the inhibition zone for each treatment is different. The higher the concentration, the greater the inhibition. The 
concentration that has the strongest inhibition is the concentration of $40 \%$. Further, data on the effect of concentration of Callyspongia biru extract on S. aureus and E. coli bacteria can be seen as follows:

\section{Bacteria S. aureus}

Data on the diameter of the inhibition zone of the antibacterial extract of Callyspongia biru against S. aureus bacteria are presented in table 2 below.

Table 2. Inhibitory zone diameter of . Callyspongia biru extract against S. aureus bacteria.

\begin{tabular}{lllllll}
\hline Treatment (\%) & \multicolumn{3}{l}{ Inhibition Zone Diameter $(\mathrm{mm})$} & Amount & Average \\
\cline { 2 - 5 } & 1 & 2 & 3 & & \\
\hline $\mathrm{K}_{1}$ & 14 & 13 & 14 & 41 & 13,67 \\
$\mathrm{~K}_{2}$ & 16 & 15 & 16 & 47 & 15,67 \\
$\mathrm{~K}_{3}$ & 17 & 15 & 16 & 48 & 16 \\
$\mathrm{~K}_{4}$ & 20 & 18 & 17 & 55 & 18,33 \\
$\mathrm{~K}^{+}$ & 16 & 15 & 16 & 47 & 15,67 \\
$\mathrm{~K}^{-}$ & - & - & - & - & - \\
\hline
\end{tabular}

Note table 2:

$\mathrm{K} 1=10 \%$ concentration

$\mathrm{K} 2=20 \%$ concentration

$\mathrm{K} 3=30 \%$ concentration

$\mathrm{K} 4=40 \%$ concentration

$\mathrm{K}+$ (positive control): Tetracycline

$\mathrm{K}$ - (negative control): sterile Aquades

Table 2 above also shows the effect of the concentration of Callyspongia biru extract on $S$. aureus bacteria in each treatment. The smallest average is at a concentration of $10 \%$ which is $13.67 \mathrm{~mm}$ and the largest average is at a concentration of $40 \%$ with a value of $18.33 \mathrm{~mm}$.

2. Escherichia coli

The effect of the concentration of the anti-bacterial extract of Callyspongia biru on the growth of the comparison bacteria E.coli can be seen in table 3 below.

Table 3. Inhibitory zone diameter of C.biru extract towards E.coli bacteria.

\begin{tabular}{llllll}
\hline \multirow{2}{*}{$\begin{array}{l}\text { Treatment } \\
(\%)\end{array}$} & \multicolumn{3}{l}{ Inhibition Zone Diameter $(\mathrm{mm})$} & Amount & Average \\
\cline { 2 - 5 } & 1 & 2 & 3 & & \\
\hline $\mathrm{K}_{1}$ & 16 & 16 & 16 & 48 & 16 \\
$\mathrm{~K}_{2}$ & 16 & 17 & 17 & 50 & 16,67 \\
$\mathrm{~K}_{3}$ & 17 & 17 & 18 & 52 & 17,33 \\
$\mathrm{~K}_{4}$ & 18 & 18 & 20 & 56 & 18,67 \\
$\mathrm{~K}^{+}$ & 15 & 14 & 16 & 45 & 15 \\
$\mathrm{~K}^{-}$ & - & - & - & - & - \\
\hline
\end{tabular}

Table 3:

$\mathrm{K} 1=10 \%$ concentration

$\mathrm{K} 2=20 \%$ concentration

$\mathrm{K} 3=30 \%$ concentration

$\mathrm{K} 4=40 \%$ concentration

$\mathrm{K}+$ (positive control): Tetracycline

$\mathrm{K}$ - (negative control): sterile Aquades 
Table 3 also shows the difference in the average of each treatment with the smallest average at a concentration of $10 \%$ with a value of $16 \mathrm{~mm}$ and the largest average is at a concentration of $40 \%$, which is $18.67 \mathrm{~mm}$. From the three tables presented above, it can be stated that the diameter of the inhibition zone increased as the concentration of the given Callyspongia biru extract increased. In this study, tetracycline was used as a comparison solution. 0.0003 gram of tetracycline was weighed and then dissolved with water to reach $10 \mathrm{ml}$. Yellow tetracycline solution, which was used as a positive control. The following is data on the effect of tetracycline on bacterial isolates from seaweed that was attacked by ice-ice disease, $\mathrm{S}$. aureus and E. coli bacteria.

Table 4. Effect of tetracycline on isolated bacterial, S. aureus and E.coli.

\begin{tabular}{llllll}
\hline Bacteria & \multicolumn{9}{l}{ Inhibition Zone Diameter (mm) } & Amount & Average \\
\cline { 2 - 5 } & 1 & 2 & 3 & & \\
\hline $\begin{array}{l}\text { Seaweed isolate (Vibrio sp and } \\
\text { Pseudomonas } s p \text { ) }\end{array}$ & 18 & 20 & 22 & 60 & 20 \\
S.aureus & 16 & 15 & 16 & 47 & 15,67 \\
E.coli & 15 & 14 & 16 & 45 & 15 \\
\hline
\end{tabular}

Table 4 above shows the diameter of the inhibition zone in the 3 types of bacteria tested due to the effect of tetracycline. It is also seen that there is a difference in the average diameter of the inhibition zone. Bacterial isolates from seaweed diseased with ice-ice had the largest average of $20 \mathrm{~mm}$, and then followed by $15.67 \mathrm{~mm} \mathrm{~S}$. aureus bacteria and $15 \mathrm{~mm}$ E. coli bacteria.

The data obtained in table 1, table 2 and table 3 above ilustrate different results. The Callyspongia biru extract was more active on isolated bacterial from ice-ice diseased seaweed than on $S$. aureus and E. coli bacteria. The data in table 1 reveals an analysis of variance (one way ANOVA). The complete summary of the analysis results can be seen in table 5 .

Tabel 5. Summary of ANOVA the effect of concentration (\%) of Callyspongia biru extract on the growth of bacteria causing ice-ice.

\begin{tabular}{lllllll}
\hline Source of diversity & Free Degrees & $\begin{array}{l}\text { Number of } \\
\text { Squares }\end{array}$ & $\begin{array}{l}\text { Middle } \\
\text { Square }\end{array}$ & F. Count & Sign. & $\begin{array}{l}\text { F.Table } \\
5 \%\end{array}$ \\
\hline Treatment & 3 & 156,67 & 52,22 & $26,11^{*}$ & .000 & 4,07 \\
Error & 8 & 16,00 & 2,00 & & & \\
Total & 11 & 172,67 & & & & \\
\hline
\end{tabular}

Description: * : Very real effect

The results of the ANOVA in table 5 above show that the value of $\mathrm{F}$. Count $=26.11>$ F. Table $5 \%=4.07$ ( $\mathrm{db}$ for the numerator of 3 and $\mathrm{db}$ for the denominator of 8 ). Because F.Calculate $>$ F.Table, this research hypothesis is accepted. Thus, it can be concluded that the concentration treatment has a very significant effect on the growth of ice-ice bacteria. To find out the treatment or concentration that gave a very real effect, it was continued with the Tukey's Honest Significant Difference Analysis (HSD) at a significance level of 5\%. The results of the significant difference test can be seen in table 6 . 
Table 6. The results of the Honestly Significant Difference (HSD) test in the diameter of the ice-ice bacteria growth inhibition zone.

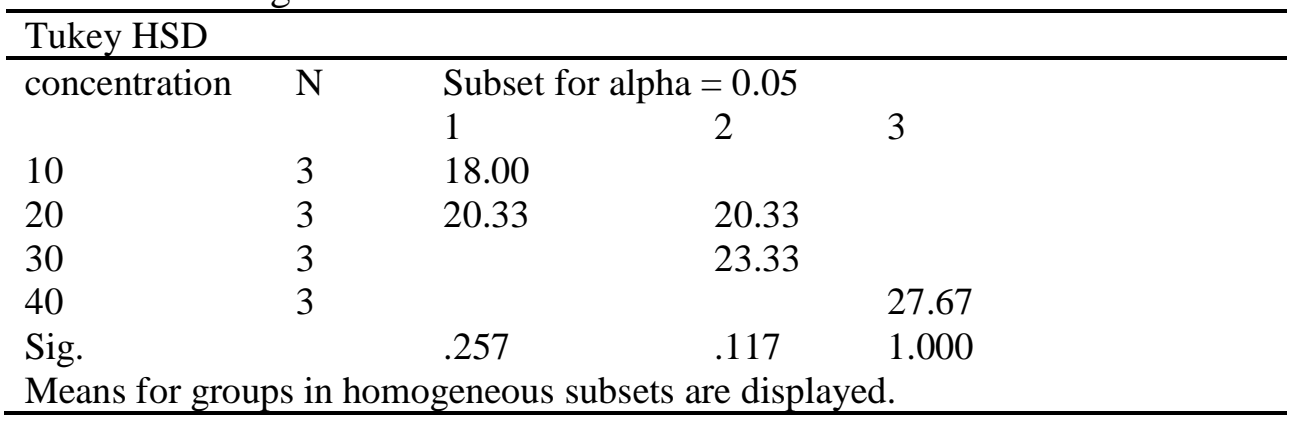

The results of the Honest Significant Difference test in table 6 above show the average value of the $10 \%$ concentration treatment is in subset 1 . The average value of the $20 \%$ concentration treatment is in subsets 1 and 2 . The average value of the $30 \%$ concentration treatment is in subset 2 . The result reveals that these three concentrations are not significantly different. While the average value of the $40 \%$ concentration treatment is in subset 3 which shows a very significant difference with other treatments. From the results obtained, it can be concluded that the higher the concentration of Callyspongia biru extract, the great the antibacterial power. In the Callyspongia biru extract, the concentration that showed the strongest/maximum inhibition on the growth of ice-ice bacteria was at the concentration of $40 \%$. Callyspongia biru that is still wet is aerated to dry for 7 days. After drying, it is mashed and taken as much as 300 grams to be macerated for 5 days with $750 \mathrm{ml}$ of gasoline solvent for then be evaporated. Petrol gasoline is a non-polar solvent that dissolves non-polar compounds based on the solubility principle. Thus, the extracts obtained from evaporation containing non-polar compounds. The filtrate obtained was $21 \mathrm{ml}$, black in color and had a sharp aroma. Then $10 \mathrm{ml}$ of the filtrate was taken to make concentrations of $10 \%, 20 \%, 30 \%$ and $40 \%$ by dilution.

Callyspongia biru extract was proven to inhibit the growth of bacteria from the ice-ice diseased Kappaphycus alvarezii seaweed as seen from the clear zone produced around the area of bacterial growth. In addition, this extract was also active on the compared bacteria, namely S.aureus and E.coli which also seen from the presence of a clear zone produced. According to De Voogd et al. (2007), Callyspongia biru extract contains amphitoxin bioactive compounds $\mathrm{A}$ and $\mathrm{B}$. Amphitoxin is a promising compound because it is active in various test organisms and various biological tests (Wikanta, et al. 2011). This amphitoxin which is also anti-microbial has a mechanism to kill microbial growth, including damaging the microbial cell wall, changing the permeability of the cytoplasmic membrane which causes the release of nutrients from the microbial cell, inhibiting the work of enzymes in microbial cells and inhibiting the synthesis of nucleic acids and proteins, and releasing free sulfhydryl groups (Jawetz et al, 1996 in Wibawaty, 2012). In determining the antibacterial activity of Callyspongia biru extract, agar diffusion method was used. Determination of the inhibition zone diameter category according to Cappuccino and Sherman (1983) in Tokan et al, (2012) using standard tetracycline antibiotics, namely the resistant category $14 \mathrm{~mm}$, the medium category $15-18 \mathrm{~mm}$ and the susceptible category $19 \mathrm{~mm}$. The tetracyclines (positive control) in this study had an average diameter of $15-20 \mathrm{~mm}$ of moderate to susceptible inhibition zones. The effect of tetracycline that has been tested shows that bacterial isolates from seaweed with ice-ice disease have an average inhibition zone diameter of $20 \mathrm{~mm}$, including the susceptible category. Then, the average $S$. aureus bacteria was $15.67 \mathrm{~mm}$ which was included in the medium category and the average E. coli bacteria was $15 \mathrm{~mm}$ which also included the medium category. 
In addition, according to Davis and Stout (1971) in Pantun (2011) in Keo (2013), if the diameter of the inhibition area is $5 \mathrm{~mm}$ or less, the inhibitory activity is categorized as weak, 6-10 $\mathrm{mm}$ is categorized as moderate, $11-19 \mathrm{~mm}$ is categorized as weak, and $20 \mathrm{~mm}$ or more is considered as very strong. The average diameter of the inhibition zone on the growth of ice-ice bacteria for a $10 \%$ concentration was $18 \mathrm{~mm}$, categorized as strong. The concentration of $20 \%$ has an average diameter of $20.33 \mathrm{~mm}$, categorized as very strong. For a concentration of $30 \%$, the average diameter of the inhibition zone was $23.33 \mathrm{~mm}$, which was classified as very strong. Furthermore, the average $40 \%$ concentration of $27.67 \mathrm{~mm}$ is also classified as very strong category. In the comparison bacteria $S$. aureus, the overall diameter of the inhibition zone ranged from 13-18 mm, which means that it belongs to the strong category. For comparison bacteria, E.coli ranging from $16-18 \mathrm{~mm}$ is also included in the strong category. This means that C.biru extract is not only active in inhibiting the growth of ice-ice bacteria isolates but also can inhibit the growth of $S$. aureus and $E$. coli bacteria. From the results above, it has been proven that Callyspongia biru extract besides being able to inhibit the growth of gram-positive bacteria isolates from seaweed, can also inhibit the growth of gram-negative bacteria represented by E.coli bacteria. This proves that Callyspongia biru extract has a broad spectrum of inhibition in inhibiting bacterial growth. The calculated $\mathrm{F}$ value from the data on the diameter of the ice-ice bacterial inhibition zone is greater than the F. table $(\mathrm{F}$. Count $=26.11>$ F.Table $5 \%=4.07)$. This means that the hypothesis of this study is accepted, that different concentrations of Callyspongia biru extract have different effects on the growth of bacterial isolates from Kappaphycus alvarezii seaweed with ice - ice disease. Further test results with the Honest Significant Difference Test (HSD) shows, when associated with the four concentrations $(10 \%, 20 \%, 30 \%$ and $40 \%)$, then the $40 \%$ concentration had a very significantly different effect with other concentrations. (is in subset 3). In addition to depending on concentration, according to Tokan, et al (2012), the activity of an antimicrobial is also influenced by the following factors: (1) population size. A large population takes a longer time to kill than a small population, (2) Population composition. (3) The effectiveness of the agent varies, depends on the nature of the organism, the concentration or intensity of the antimicrobial agent, (4) the duration of exposure. The longer a population is exposed to an antimicrobial agent, the more members of that population are killed, (5) Temperature. An increase in temperature sometimes increases the activity of a chemical substance. Often, lower concentrations of chemicals can be used at higher temperatures, (6) Local environment. Controlled populations are not isolated, but are surrounded by environmental factors that may help or protect them from destruction. The Callyspongia biru extract in this study only reached the level of inhibiting bacterial growth but have not touch the level of bacteria killing. From the test results of the effect of the concentration of Callyspongia biru extract on the growth of bacterial isolates from seaweed Kappaphycus alvarezii with ice-ice disease, it is found that the higher the concentration, the greater the diameter of the inhibition zone, which means the antibacterial inhibition is stronger. Or in other words, the concentration is directly proportional to the inhibitory power or the diameter of the resulting inhibition zone

\section{CONCLUSION}

From the results of this study it can be concluded that:

1. Callyspongia biru extract with different concentrations has different effects in inhibiting the growth of bacteria that causes ice-ice disease in Kappaphycus alvarezii seaweed.

2. From the four concentrations used $(10 \%, 20 \%, 30 \%$ and $40 \%)$, the one with the strongest inhibition was at a concentration of $40 \%$. Thus it is infered that the higher the concentration the stronger the inhibition. 


\section{REFERENCES}

Amir, I. \& Budiyanto. (1996). Mengenal Spons Laut (Demospongiae) Secara Umum. Oseana, XXI (2), 15-31.

Aris, M. (2011). Identifikasi, Patogenisitas Bakteri dan Pemanfaatan Gen 16srrna untuk

Deteksi Penyakit Ice-ice pada Budidaya Rumput Laut (Kappaphycus alvarezii). Skripsi. Bogor: Institut Pertanian Bogor.

Aslan, L. (1998). Budidaya Rumput Laut. Jogyakarta : Kanisius.

Astawan, M., Koswara, S., \& Herdiani, F. (2004). Pemanfaatan Rumput Laut (Eucheuma cottonii)

untuk Meningkatkan Kadar Iodium dan Serat Pangan pada Selai dan Dodol. Jurnal.Teknol. dan Industri Pangan, XV(1), 61-69.

De Voogd, N.J. (2004). Callyspongia (Euplacella) biru spec. nov. (Porifera: Demospongiae:

Haplosclerida) from Indonesia. Zool Med Leiden, 78, 477- 483.

De Voogd, N.J., Joris J.H.H., and Bert W.H. (2005). Evaluation of the ecological function of amphitoxin in the reef-dwelling sponge Callyspongia (Euplacella) biru (Haplosclerida: Callyspongiidae) at southwest Sulawesi, Indonesia. Contributions to Zoology, 74, 51-59.

De Voogd, N.J., Becking, L.E., Nakao, Y., Van Soest, R.W.M., Fusetani, N., and Matsunaga,

S. (2007). Perplexing Distribution of 3-alkylpyridines in haplosclerid Sponges. Porifera Research: Biodiversity, Innovation and Sustainability, 173-178.

Fariska , Y. (2010). Studi Ekologi Senyawaan Spons Callyspongia aerizusa

Desqueyroux faundez, 1984 Dari Kepulauan Seribu, Jakarta. Skripsi. Departemen Biologi, FMIPA UI, Kampus UI Depok. Jawa Barat.

Hanani, E., Mun'im, A., \& Sekarini, R. (2005). Identifikasi Senyawa Antioksi dan Dalam Spons Callyspongia sp Dari Kepulauan Seribu. Majalah Ilmu Kefarmasian, II (3), $127-133$.

Ismet, M.S. (2007). Penapisan Senyawa Bioaktif Spons Aaptos aaptos dan Petrosia sp. Dari Lokasi yang Berbeda. Skripsi. Bogor : Institut Pertanian Bogor.

Izza, I. (2011). Isolasi, Karakterisasi Dan Identifikasi Bakteri Endofit Dari Tanaman Mahkota Dewa (Phaleria macrocarpa) yang Berpotensi Sebagai Penghasil Antimikroba. Skripsi. Yogyakarta : Universitas Islam Negeri Sunan Kalijaga.

Kamlasii, Y. (2011). Pengembangan Budidaya Rumput Laut di Kecamatan Kupang Barat, Kabupaten Kupang. Kupang : Balai Perikanan.

Keo, J.A. (2012). Daya Antibakteri Ekstrak Kulit Batang Faloak (Sterculia Urceolata Smith) Terhadap Bakteri Acetobacter Acetti Dalam Nira Lontar (Borassus Sundaicus Becc). Skripsi. Kupang : Undana.

Kordi, M.G.H. (2011). Kiat Sukses Budidaya Rumput Laut. Jogyakarta : Penerbit ANDI. Krisyuninda, M.P. (2010). Uji Toksisitas Fraksi Spons callyspongia sp. Dengan

Metode Brine Shrimp Test (BST) dari Perairan Pasir Putih Situbondo. Skripsi. Surabaya : Institut Teknologi Sepuluh Nopember.

Poncomulyo, T. Maryani, H. \& Kristiana, L. (2006). Budidaya dan Pengolahan Rumput Laut. Jakarta : PT. Agromedia Pustaka.

Priadie, B., Rinjani, R.R., \& Arifin, Z.M. (2009). Isolasi dan Identifikasi Bakteri dari Perairan Tercemar untuk Menunjang Upaya Bioremediasi Badan Air. Bandung : Pusat Litbang Sumber Daya Air.

Rahmawaty, N., Handayani, D., \& Mulyanti, N. (2009). Skrining Aktivitas Sitotoksik Ekstrak dan Fraksi Beberapa Jenis Spon Laut Asal Pulau Mandeh, Sumatera Barat. Pekanbaru: Sekolah Tinggi Ilmu Farmasi Riau.

Santoso, L., dan Nugraha, Y.T. (2008). Pengendalian Penyakit Ice-Ice Untuk Meningkatkan Produksi Rumput Laut Indonesia. Lampung : Jurnal Saintek Perikanan, 3(2), 37 43. 
Subhan, B. (2009). Tingkat Kelangsungan Hidup dan Pertumbuhan Spons Jenis Petrosia (Petrosia) nigricans Lindgren, 1897 and Aaptos aaptos (Schmidt, 1864) yang Ditransplantasikan di Perairan Pulau Pari, Kepulauan Seribu, Jakarta. Bogor : Institut Pertanian Bogor.

Suparno. 2005. Skripsi. Kajian Bioaktif Spons Laut (Porifera: Demospongiae) Suatu Peluang Alternatif Pemanfaatan Ekosistem Karang Indonesia dalam Bidang Farmasi. Bogor : Institut Pertanian Bogor.

Suparno , Soedharma, D., Zamani. N.P., Rachmat. R. (2009). Transplantasi Spons Laut Petrosia nigricans . Ilmu Kelautan, 14 (4), 54-6.

Suryati, E., \& Muliani. (2002). Efektivitas Penggunaan Bioaktif Sponge untuk Penanggulangan Bakteri Aeromonas sp. Pada Nener Bandeng, Chanoschanos forskal. Jurnal Penelitian Perikanan Indonesia, 8 (2).

Tamamma, M.Y., S. Fakhriyyah, \& H.A. Pasanrangi. (2011). Kontribusi Usaha Budidaya Rumput Laut (Eucheuma cottonii) Terhadap Pendapatan Keluarga. Jurnal Perikanan. Sulawesi Selatan.

Tista, G.N.B. (2011). Efektifitas ekstrak Buah Mengkudu (Morinda citrifolia L)Terhadap Pertumbuhan Isolat Bakteri Streptococcus mutans. Skripsi. Denpasar : UNUD.

Tokan, M.K., A.S. Ardan, M.M. Immakulata, \& A.S. Sudibyo. (2012). Analisis Daya Hambat Ekstrak Callyspongia terhadap Isolat Bakteri dari Rumput Laut Kappaphycus alvarezii yang Berpenyakit Ice-ice. Kupang : Universitas Nusa Cendana.

Tokan, M.K. (2011). Analisis Potensi Antimikroba dan Kemungkinan Pemanfaatannya Sebagai Obat Antidermatomikosis. Jurnal Matematika dan IPA, Kupang : Universitas Nusa Cendana

Wikanta, T., D. Gusmita, L. Rahayu, \& E. Marraskuranto. (2012). Kajian Awal Bioaktivitas Ekstrak Etanol dan Fraksinya dari Spons Callyspongia sp. Terhadap Sel Lestari Tumor hela. JPB Perikanan, 7 (1), 1-10.

Yulianty, R.,H. Rante, G. Alam, dan A. Tahir. (2011). Skrining dan Analisis klt bioautografi Senyawa Antimikroba Beberapa Ekstrak Spons Asal Perairan Laut Pulau Barrang Lompo, Sulawesi Selatan. Majalah Obat Tradisional, 16 (2), 88 - 94. 